\title{
Proliferative activity of oocytes in multi-oocyte follicles of bovine ovary
}

\section{Atividade proliferativa em folículos multi-oócitos na espécie bovina}

\author{
Reginaldo Luis Oliveira'; Katia Cristina Silva-Santos²; Suellen Miguez González; \\ Camila Bizarro-Silva ${ }^{3}$; Fernanda Zandonadi Machado'; Ana Paula Frederico \\ Rodrigues Loureiro Bracarense ${ }^{4}$; Marcelo Marcondes Seneda ${ }^{5 *}$
}

\begin{abstract}
We characterized the proliferative activity of multi-oocyte follicles with anti-nuclear antigen of proliferating cells $(\mathrm{PCNA})$. Ovaries $(\mathrm{n}=12)$ from heifers were processed for histology. From 789 multi-oocytes follicles observed, only 11 were considered appropriated for immunostaining, since they presented all nuclei of the oocytes clearly visible. All multi-oocyte follicles were positive for PCNA, but some oocytes showed no proliferative activity. We conclude that oocytes in multi-oocyte follicles seem to be in different stages of the cell cycle.
\end{abstract}

Key words: PCNA. Cattle. Folliculogenesis. Multiple oocytes.

\section{Resumo}

O objetivo deste trabalho foi caracterizar a atividade proliferativa de folículos multi-oócitos com antígeno marcador de proliferação celular (PCNA). Ovários $(\mathrm{n}=12)$ de novilhas foram processados para histologia. A partir de 789 folículos multi-oócitos identificados, somente 11 foram considerados adequados para imunohistoquímica por apresentarem todos os núcleos claramente visíveis. Todos os folículos multi-oócitos foram positivos para PCNA, mas alguns oócitos não apresentaram marcação. Concluímos que oócitos presentes em folículos multi-oócitos parecem estar em diferentes fases do ciclo celular.

Palavras-chave: PCNA. Bovinos. Foliculogênese. Múltiplos oócitos.

\footnotetext{
${ }^{1}$ Mestres, Programa de Pós-Graduação em Ciência Animal, Universidade Estadual de Londrina, UEL, Centro de Ciências Agrárias, CCA, Londrina, PR, Brasil. E-mail: rethasmo@hotmail.com; suellenmgonzalez@gmail.com; ferzmachado@hotmail.com

2 Dra , Programa de Pós-Graduação em Ciência Animal, UEL, CCA, Londrina, PR, Brasil. E-mail: katiasilva.vet@gmail.com

${ }^{3}$ Discente de Doutorado, Programa de Pós-Graduação em Ciência Animal, UEL, CCA, Londrina, PR, Brasil. E-mail: camilabizarros@gmail.com

${ }^{4}$ Prof $^{\mathrm{a}} \mathrm{Dr}^{\mathrm{a}}$, Departamento de Medicina Veterinária Preventiva, UEL, CCA, Londrina, PR, Brasil. E-mail: ana.bracarense29@ gmail.com

${ }_{5}^{5}$ Prof. Dr., Departamento de Clínicas Veterinárias, UEL, CCA, Londrina, PR, Brasil. E-mail: mseneda@uel.br

* Author for correspondence
} 


\section{Introduction}

The occurrence of follicles with a single oocyte is classically described for mammals, but many authors have reported follicles with two or more oocytes delimited by a membrane in a single follicle (LUCCI et al., 2002; REYNAUD et al., 2009; SILVA-SANTOS; SENEDA, 2011). These follicles have been described using different names: multi-oocyte follicles, polyovocytaires follicles (REYNAUD et al., 2009, 2010), multinucleated eggs (KENT JR, 1962) and polyovular follicles (KENNEDY, 1924; ALM et al., 2010).

Some hypotheses suggest that the occurrence of multi-oocyte follicles in adult female ovaries occurs through mitotic division, with multiple oocytes arising from primordial follicles during folliculogenesis, due to the high rate differentiation of cells during development of the follicles (KENNEDY, 1924). Other authors believe that the origin of these structures in adult animals occurs due to the failure of germ cell division during the early stages of folliculogenesis, for example, human (ZEILMAKER et al., 1983), caprine (LUCCI et al., 1999) and mammalian (TINGEN et al., 2009). Recently, a new theory has been proposed suggesting that the granulosa cells are invasive and may cause a fusion in the adjacent cells (mouse: GAYTAN et al., 2014).

There is little information about the viability of these oocytes in adult cattle and nothing is known about its proliferative activity. In this way, the goal of this study was to investigate the cell proliferation of multi-oocytes follicles in bovine ovaries.

\section{Material and Methods}

\section{Collection and transport of the ovaries}

Ovaries $(\mathrm{n}=12)$ of Bos taurus indicus heifers (Nellore), at 20-24 months of age, were obtained from a local slaughterhouse, $40 \mathrm{~km}$ away from the lab (approximately 30 minutes) and transported at $20^{\circ} \mathrm{C}$. After transport, ovaries were washed in $70 \%$ ethanol for 10 seconds and twice in $0.9 \%$ saline solution. A sagittal section was made at the greater curvature, resulting in two half-ovaries, which were then immersed in Bouin fixative for histological processing.

\section{Histological processing}

The half-ovaries were fixed in Bouin solution for 24 hours, washed in running water for an hour and then placed in $70 \%$ alcohol. Dehydration occurred in increasing concentrations of alcohol. Later, the ovaries were diaphanized in xylene, infiltrated and embedded in paraffin. After paraffin embedding, serial $5 \mu \mathrm{m}$ sections were taken in a rotary microtome (Leica ${ }^{\circledR}$ type, Wetzlar, Germany). Each slide contained two replicates, one for staining with PAS (periodic acid-Schiff) and hematoxylin and the other for the assessment of cell proliferation using immunohistochemical techniques.

\section{Evaluation of cell proliferation by} immunohistochemistry

Staining by PAS was used to determine which histological sections contained multi-oocyte follicles and showed the basement membrane and the zona pellucida. After identification of the multi-oocyte follicles in slides stained with PAS, the immunohistochemistry was performed on the second section on the slide.

Cell proliferation was evaluated by immunohistochemistry using biotinylated monoclonal antibody PCNA (proliferating cell nuclear antigen, 1:200 dilution, Clone PC1O, $Z^{Z Y M E D}{ }^{\circledR}$, local). Histological sections were rehydrated and subjected to antigen retrieval with citrate solution ( $\mathrm{pH}$ 6.0) in a microwave oven for 12 minutes. Subsequently, the sections were subjected to blocking of endogenous peroxidase and $\mathrm{H}_{2} \mathrm{O}_{2}$ in $50 \%$ methanol (v/v) for 20 minutes. The anti-PCNA antibody was incubated overnight (18 hours). After incubation and conjugation of the secondary 
antibody (1:500) for 20 minutes, the reaction was stopped using diaminobenzidine substrate (DAB) for approximately three minutes. To make the slides, the material was counter-stained with hematoxylin.

To evaluate cell proliferation, the follicles containing one or more oocytes were classified according to the developmental stage (primordial, primary, secondary and antral follicles) and in accordance with a score of reactivity to PCNA, which took into consideration the number of granulosa cells and reactivity (PCNA-positive or negative) in the oocytes. The reactivity of PCNA in granulosa cells from the follicles was evaluated by visual scores as follows: 1- no PCNA-positive cells, 2- up to $33 \%$ of granulosa cells positive, 3$34 \%-66 \%$ of granulosa cells positive, and $4-67 \%$ $-100 \%$ of granulosa cells positive. We compared the proliferation of granulosa cells of follicles with one or more oocytes and their proliferative activity during different stages of development (primordial and primary). In this work, only a descriptive analysis of the data.

\section{Results}

Considering the critical requirement of all nuclei of the oocytes be clearly visible at the same histological sections, only eleven multi-oocyte follicles were considered, from thousands of slides and 789 ovarian follicles identified. Ten multioocyte follicles were primordial $(1.26 \%, 10 / 789)$ and one was in a primary stage $(0.12 \%, 1 / 789$; Table 1). One primordial follicle contained three and all others showed two oocytes. The multi-oocyte follicles classified morphologically as primordial had three to nine flat granulosa cells (Figure 1B).

Positive staining was observed in at least one oocyte of multi-oocyte follicles, whereas the other oocytes had no indication of proliferation or a lower intensity of proliferative activity (Figure 1A, C and D). The multi-oocyte follicles had a mean diameter of $31-48 \mu \mathrm{m}$ and their respective oocytes with $23-$ $36 \mu \mathrm{m}$ in diameter. While the primary multi-oocyte follicle had a diameter of $51 \mu \mathrm{m}$ and its respective oocytes ranged from $30-39 \mu \mathrm{m}$ in diameter.

Table 1. Counts of multi-oocytes follicles and characterization of preantral follicles in female cattle.

\begin{tabular}{cccccccc}
\hline Classification & $\begin{array}{c}\text { Number } \\
\text { follicles }\end{array}$ & Normal & Atretic & $\begin{array}{c}\text { Follicular quality } \\
\text { Oocyte follicles } \\
\text { (n/total) }\end{array}$ & $\begin{array}{c}\text { PCNA } \\
\text { score }\end{array}$ & $\begin{array}{c}\text { Oocyte diameter } \\
\text { (average) }\end{array}$ & $\begin{array}{c}\text { Granulosa } \\
\text { cell count }\end{array}$ \\
\hline Primordial & 10 & 10 & 0 & $\begin{array}{c}2(9 / 10) \\
3(1 / 10)\end{array}$ & $3-4$ & $23-36 \mu \mathrm{m}$ & $3-9$ \\
Primary & 1 & 1 & 0 & $2(1 / 1)$ & $3-4$ & $30-39 \mu \mathrm{m}$ & 17 \\
\hline
\end{tabular}


Figure 1. A. Photomicrographs from primordial follicles marked by the anti-PCNA antibody and classified according to granulosa cell marking scores. Score 1 . Bars $=50 \mu \mathrm{m}$. B. Primary multi-oocyte follicle with two oocytes (black arrow). $40 \mathrm{X}$ objective. Bar $=50 \mu \mathrm{m}$. C. Primordial multi-oocyte follicle (transition) showing two oocytes labeled by the anti-PCNA antibody (black arrow). 40x. D. Primary multi-oocyte follicle showing two oocytes: one labeled and another weakly marked (black arrow). 40x. Bar $=50 \mu \mathrm{m}$.
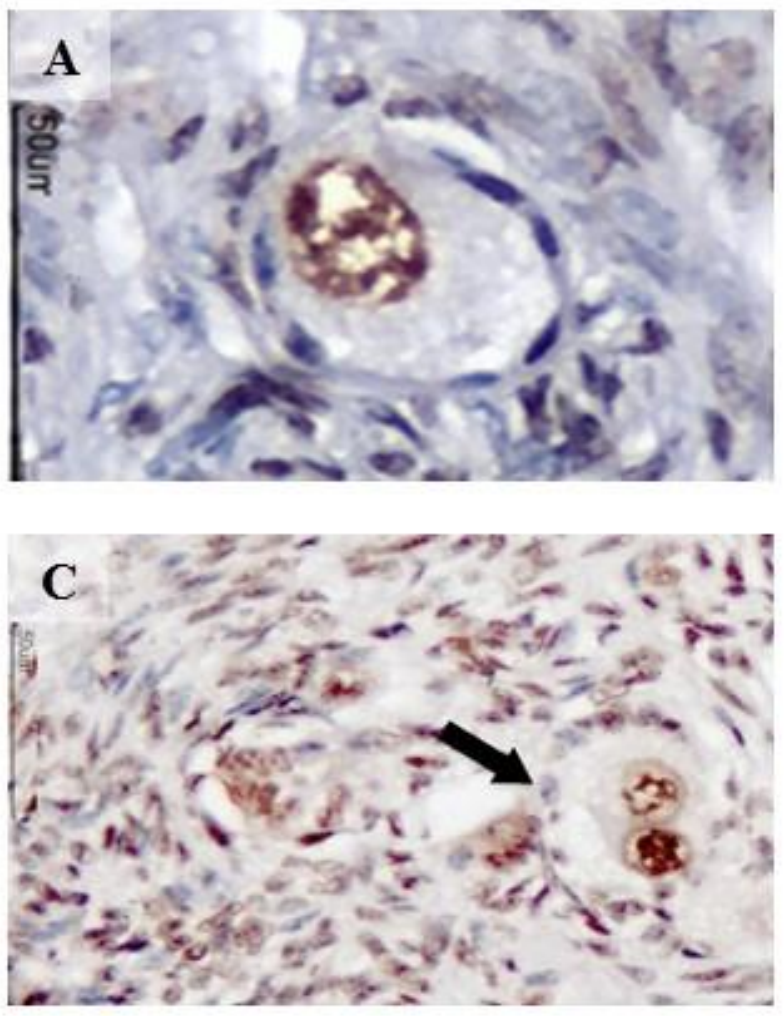

\section{Discussion}

To our knowledge, this is the first report describing proliferative activity of oocytes from multi-oocyte follicles in adult cattle. Our results showed that the immunohistochemistry for PCNA was positive in multi-oocyte follicles in primordial and primary stages, which had been previously demonstrated only for uni-oocyte follicles in rats, bovine fetuses and pigs (OKTAY et al., 1995; WANDJI et al., 1996; TOMÁNEK; CHRONOWSKA, 2006).

The occurrence of multi-oocyte follicles in different animal species have been observed since the early twentieth century. Follicles containing two to five oocytes have been reported in dogs, cats, rabbits, guinea pigs and chickens (KENNEDY, 1924). Telfer and Gosden (1987) reviewed 15
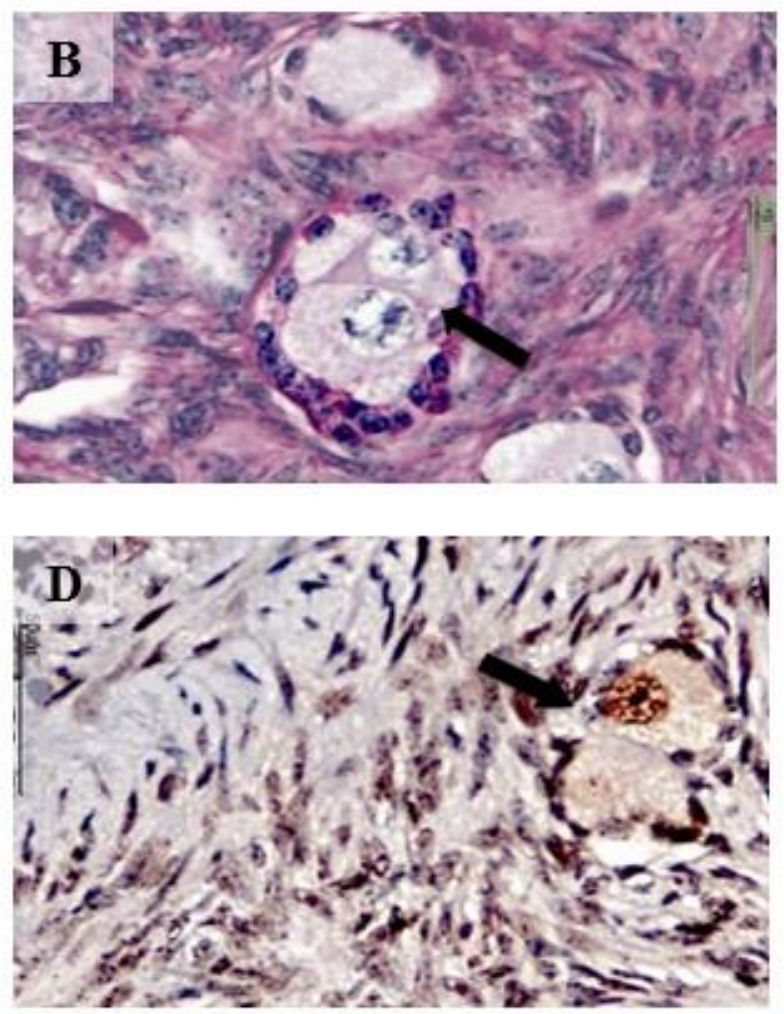

mammalian species and found that the incidence of follicles with a single oocyte was predominant, but the incidence of multi-oocyte follicles was observed in some species, such as rabbits (1\%), humans (3\%) and dogs (14\%). Despite the long time since the first report and also the prevalence in many species, it is interesting to observe the lack of information about these ovarian structures. We believe it is caused by the tough challenge for getting all nuclei of the oocytes at the same view in the histological section. We estimate that less than $0.01 \%$ of all multioocytes follicles were identified under this ideal condition.

Multi-oocyte follicles have been reported during all stages of folliculogenesis, from primordial through pre-ovulatory stages, in bitches (TELFER; GOSDEN, 1987; PAYAN-CARREIRA; PIRES, 
2008) and cows (IRELAND et al., 2008; SILVASANTOS; SENEDA, 2011). However, there is no conclusion about the presence of these structures in adults, and it is not known whether multi-oocyte follicles are involved in folliculogenesis. In this way, we highlight our results showing positive PCNA staining, which demonstrates these oocytes are active and possibly can be considered in some stage of follicular development.

The frequency of multi-oocyte follicles may vary between species, within species and between individuals. The three species with the highest incidence of multi-oocyte follicles are possums, with up to 100 oocytes per follicle and bitches, with almost $70 \%$ having at least one multi-oocyte follicle in the ovary (REYNAUD et al., 2010). For cattle, the prevalence seems to widely differ between indicus and taurus ovaries. The proportion of multioocytes follicles in taurus ranged from 0.3 to $5.4 \%$ (IRELAND et al., 2008) whereas in indicus ovaries it was high as $41 \%$ (SILVA-SANTOS; SENEDA, 2011). This higher proportion of multi-oocytes follicles in indicus females seems to be an interesting field for future studies, considering the also higher proportion of antral follicles in these females, when comparing with taurus cattle (PONTES et al., 2010, 2011).

The differences in the signal of proliferative activity in the oocytes included in the same follicle is unclear. A possible explanation would be a different stage of proliferation of these oocytes. This hypothesis is quite intriguing if we consider these oocytes should attend the same timing for growing and development, since they are in the same follicular environment. Another possibility is a kind of competition between oocytes enclosed in the same follicle; thus, only one of the oocytes would reach the maturation and ovulation. In this way, the putative subordinate oocytes should become apoptotic or degenerate during growth and maturation phases. All these proposals are just hypothetical, since the other reports at the literature only describe the occurrence of multi-oocyte follicles in adult cattle, but not the proliferative activity (IRELAND et al., 2008; SILVA-SANTOS; SENEDA, 2011).

A fact that aroused attention was that in most of the multi-oocyte follicles only one oocyte had immunostaining, and often the second oocyte did not show marking, or when marking was weak and less intensity than the first oocyte. These findings suggest some hypotheses. The first hypothesis is that oocytes are in different stages of cell division, since the anti-PCNA antibody has higher G1 and $\mathrm{S}$ cell cycle expression, decreasing later in the G2 and M phases (KURKI et al., 1988; SCOTT et al., 1991). Another possible explanation could be a sort of competition or dominance between the oocytes included in the same follicle. It is possible that only one oocyte reaches the final stage of maturation and is released at the time of ovulation, with the others entering into apoptosis or degeneration during the growth and maturation phases that precede this period.

It is also interesting to note the difference between the diameters of the ovarian follicles with one or more oocytes. Considering that, the ovarian follicular population presents a progressive increase in the diameter of the follicles and oocytes according to the follicular development (primordial, primary, secondary and antral). According to the literature, the mean diameter of the primordial and primary follicles are $36 \mu \mathrm{m}$ and $48.5 \mu \mathrm{m}$, respectively, and $28.1 \mu \mathrm{m}$ and $31.7 \mu \mathrm{m}$ for the corresponding oocytes (KACINSKIS et al., 2005). Our study found multi-oocyte follicles with diameters close to that described for follicles with an oocyte.

In conclusion, this study examined reactivity to cell proliferation marker PCNA in granulosa cells and one or more enclosed oocytes of multi-oocyte follicles from adult cattle females. The positive signal of immunohistochemistry in follicles containing multiple oocytes indicates that proliferative activity is occurring in multi-oocyte follicles in early stages of development in the ovaries. It is probable that 
the oocytes in multi-oocyte follicles are at different stages in the cell cycle or there is some type of dominance between oocytes in these follicles.

\section{References}

ALM, H.; KUHLMANN, S.; LANGHAMMER, M.; TUCHSCHERER, A.; TORNER, H.; REINSCH, N. Occurrence of polyovular follicles in mouse lines selected for high fecundity. Journal of Reproduction and Development, Tokyo, v. 56, n. 4, p. 449-453, 2010.

GAYTAN, F.; MORALES, C.; MANFREDI-LOZANO, M.; TENA-SEMPERE, M. Generation of multi-oocyte follicles in the peripubertal rat ovary: link to the invasive capacity of granulosa cells? Fertility and Sterility, New York, v. 101, n. 5, p. 1467-1476, 2014.

IRELAND, J. L.; SCHEETZ, D.; JIMENEZ-KRASSEL, F.; THEMMEN, A. P.; WARD, F.; LONERGAN, P.; SMITH, G. W.; PEREZ, G. I.; EVANS, A. C.; IRELAND, J. J. Antral follicle count reliably predicts number of morphologically healthy oocytes and follicles in ovaries of young adult cattle. Biology and Reproduction, Madison, v. 79, n. 6, p. 1219-1225, 2008.

KACINSKIS, M. A.; LUCCI, C. M.; LUQUE, M. C.; BÁO, S. N. Morphometric and ultrastructural characterization of Bos indicus preantral follicles. Animal Reproduction Science, Amsterdam, v. 87, n. 1-2, p. 45-57, 2005.

KENNEDY, W. P. The occurrence of polyovular graafian follicles. Journal of Anatomy, Medford, v. 58, n. 4, p. 328-334, 1924.

KENT JR, H. A. Polyovular follicles and multinucleate ova in the ovaries of young rats. The Anatomical Record, Medford, v. 142, n. 1, p. 25-29, 1962.

KURKI, P.; OGATA, K.; TAN, E. M. Monoclonal antibodies to proliferating cell nuclear antigen (PCNA)/cyclin as probes for proliferating cells by immunofluorescence microscopy and flow cytometry. Journal of Immunological Methods, Amsterdam, v. 109, n.1, p. 49-59, 1988.

LUCCI, C. M.; AMORIM, C. A.; RODRIGUES, A. P. R.; FIGUEIREDO, J. R.; BÁO, S. N.; SILVA, J. R. V.; GONÇALVES, P. B. D. Study of preantral follicle population in situ and after mechanical isolation from caprine ovaries at diferente reproductive stages. Animal Reproduction Science, Amsterdam, v. 56, n. 3-4, p. 223236, 1999.
LUCCI, C. M.; RUMPF, R.; FIGUEIREDO, J. R.; BÁO, S. N. Zebu (Bos indicus) ovarian preantral follicles: morphological characterization and development of an efficient isolation method. Theriogenology, New York, v. 57, n. 5, p. 1467-1483, 2002.

OKTAY, K.; SCHENKEN, R. S.; NELSON, J. F. Proliferating cell nuclear antigen marks the initiation of follicular growth in the rat. Biology and Reproduction, Madison, v. 53, n. 2, p. 295-301, 1995.

PAYAN-CARREIRA, R.; PIRES, M. A. Multioocyte follicles in domestic dogs: a survey of frequency of occurrence. Theriogenology, New York, v. 69, n. 8, p. 977-982, 2008.

PONTES, J. H. F.; MELO STERZA, F. A.; BASSO, A. C.; FERREIRA, C. R.; SANCHES, B. V.; RUBIN, K. C. P.; SENEDA, M. M. Ovum pick up, in vitro embryo production, and pregnancy rates from a large-scale commercial program using Nelore cattle (Bos indicus) donos. Theriogenology, New York, v. 75, n. 9, p. 16401646, 2011.

PONTES, J. H. F.; SILVA, K. C. F.; BASSO, A. C.; RIGO, A. G.; FERREIRA, C. R.; SANTOS, G. M. G.; SANCHES, B. V.; PORCIONATO, J. F.; VIEIRA, P. H. S.; FAIFER, F. S.; SENEDA, M. M. Large-scale in vitro embryo production and pregnancy rates from Bos taurus, Bos indicus, and indicus-taurus dairy cows using sexed sperm. Theriogenology, New York, v. 74, n. 8, p. 13491355, 2010.

REYNAUD, K.; HALTER, S.; TAHIR, Z.; THOUMIRE, S.; CHEBROUT, M.; CHASTANT-MAILLARD, S. Les follicules polyovocytaires. Gynécologie Obstétrique \& Fertilité, Paris, v. 38, n. 6, p. 395-397, 2010.

REYNAUD, K.; VIARIS, D. E.; LESEGNO, C.; CHEBROUT, M.; THOUMIRE, S.; CHASTANTMAILLARD, S. Follicle population, cumulus mucification, and oocyte chromatin configuration during the periovulatory period in the female dog. Theriogenology, New York, v. 72, n. 8, p. 1120-1131, 2009.

SCOTT, R. J.; HALL, P. A.; HALDANE, J. S.; VAN NOORDEN, S.; PRICE, Y.; LANE, D. P.; WRIGHT, N. A. A comparison of immunohistochemical markers of cell proliferation with experimentally determined growth fraction. The Journal of Pathology, Medford, v. 165, n. 2, p. 173-178, 1991.

SILVA-SANTOS, K. C.; SENEDA M. M. Multioocyte follicles in adult mammalian ovaries. Animal Reproduction, Belo Horizonte, v. 8, n. 3-4, p. 58-67, 2011. 
TELFER, E.; GOSDEN, R. G. A quantitative cytological study of polyovular follicles in mammalian ovaries with particular reference to the domestic bitch (Canis familiaris). Journal of Reproduction and Fertility, Middlesex, v. 81, n. 1, p. 137-147, 1987.

TINGEN, C.; KIM, A.; WOODRUFF, K. The primordial pool of follicles and nest breakdown in mammalian ovaries. Molecular Human Reproduction, Childerley, v. 15, n. 12, p. 795-803, 2009.

TOMÁNEK, M.; CHRONOWSKA, E. Immunohistochemical localization of proliferating cell nuclear antigen (PCNA) in the pig ovary. Folia Histochemica et Cytobiologica, Gdańsk, v. 44, n. 4, p. 269-274, 2006.
WANDJI, S. A.; SRSEI, V.; VOSS, A. K.; EPPIG, J. J.; FORTUNE, V. Initiation in vitro of growth of bovine primordial follicles. Biology and Reproduction, Madison, v. 55, n. 5, p. 942-948, 1996.

ZEILMAKER, G. H.; ALBERDA, A. T.; VAN GENT, I. Fertilization and cleavage of oocytes from a binovular human ovarian follicle: a possible cause of dizygotic twinning and chimerism. Fertil Steril, Fertility and Sterility, New York, v. 40, n. 6, p. 841-843, 1983. 
